\title{
Influence of Edaphic Factors on Fusarium wilt of Bell Pepper
}

\author{
Kaushal Attri, Monica Sharma* and S. K. Gupta
}

Dept. of Plant Pathology, College of Horticulture \& Forestry, Neri, Dr. Y. S. Parmar University of Horticulture and Forestry, Nauni, Solan, Himachal Pradesh (173 230), India

\section{Corresponding Author}

Monica Sharma

e-mail:dmonicasharma@gmail.com

\section{Article History}

Article ID: AR1904

Received in $20^{\text {th }}$ September, 2018

Received in revised form 20 ${ }^{\text {th }}$ October, 2018

Accepted in final form $22^{\text {nd }}$ October, 2018

\begin{abstract}
Fusarium wilt of bell pepper (Capsicum annuum L.) caused by Fusarium oxysporum f. sp. capsici is a damaging disease and causes huge losses to the crop. To study the effect of temperature and $\mathrm{pH}$ on mycelial growth of Fusarium oxysporum f. sp. capsici, an experiment was conducted under in vitro conditions. The results revealed that pathogen grew well at temperature range $15-35^{\circ} \mathrm{C}$ and $\mathrm{pH}$ range of $4.0-9.0$. However, optimum temperature for mycelial growth was recorded at $25^{\circ} \mathrm{C}\left(10.65 \mathrm{~mm}\right.$ day $\left.{ }^{-1}\right)$ followed by $30{ }^{\circ} \mathrm{C}\left(9.65 \mathrm{~mm}^{\mathrm{day}}{ }^{-1}\right)$. The most suitable $\mathrm{pH}$ level for growth of fungus was $7.0\left(12.75 \mathrm{~mm} \mathrm{day}^{-1}\right)$ followed by $6.0\left(10.70 \mathrm{~mm} \mathrm{day}^{-1}\right)$. Growth of fungus reduced drastically below 15 and above $35^{\circ} \mathrm{C}$. Similarly very low and high pH levels were not suitable for mycelial growth. To study the effect of soil temperature and soil moisture on the development of Fusarium wilt of bell pepper, an experiment was conducted in sick pots. Bell pepper seedlings were transplanted in sick pots and different soil temperature and soil moisture were maintained. It was observed that incidence of Fusarium wilt disease was maximum $(100 \%)$ at soil temperature of $25^{\circ} \mathrm{C}$ followed by $30{ }^{\circ} \mathrm{C}(75.0 \%)$ and $20^{\circ} \mathrm{C}(37.5 \%)$ while $40 \%$ soil moisture resulted in maximum disease incidence of $66.66 \%$ followed by $50 \%$ (58.33\%) and $60 \%$ (50.00\%). Hence, optimum temperature for the development of Fusarium wilt of bell pepper was $25^{\circ} \mathrm{C}$ whereas optimum soil moisture was $40 \%$.
\end{abstract}

Keywords: $\mathrm{pH}$, soil temperature, soil moisture, wilt, Fusarium wilt incidence

\section{Introduction}

Soil-borne diseases are major constraints in the production of many economically important crops, especially vegetables and ornamentals. Fusarium wilt of bell pepper, caused by Fusarium oxysporum f. sp. capsici is one of the important soil-borne vascular wilt pathogen (Gupta and Thind, 2006). The disease is a common disease in tropical and subtropical and reduces overall yield of crop. The disease was first reported in New Mexico (Leonian, 1919). Slight yellowing of lower leaves and wilting of upper leaves followed by permanent wilting of entire plant and browning of the vascular tissue are the characteristic symptoms of the disease (Smith et al., 1988; Black and Rivelli, 1990). In India, occurrence of Fusarium wilt in bell pepper and chilli has been reported from various parts of country including Jammu and Kashmir, Karnataka and Himachal Pradesh and causes up to $25 \%$ losses with disease incidence up to $75 \%$ (Singh et al., 1998; Madhukar and Naik, 2004; Anonymous, 2005). Temperature and $\mathrm{pH}$ play important role on the growth and development of Fusarium. Different species and forme specialis of Fusarium grow at the temperature range of 15-30 ${ }^{\circ} \mathrm{C}$ and at pH 5.0 and 6.0 (Landa et al., 2001; Gangadhara et al., 2004; Jaruhar and Prasad, 2011; Kumar et al., 2012). The temperature and moisture are two important parameters which greatly influence the development of Fusarium wilts in different crops (Landa et al., 2001; Mina and Dubey, 2010; Prasad and Saifulla, 2012). Chen et al. (2013) showed that F. oxysporum was able to grow at wide temperature range, and the highest growth rate was observed at $23-24{ }^{\circ} \mathrm{C}$. Scarce reports on the influence of soil temetrature and soil moisture on the development of Fusarium wilt of bell pepper are available in literature. Hence, the present investigation is concentrated on the role of temperature, $\mathrm{pH}$ and moisture on the growth, infection and development of Fusarium wilt of bell pepper. The effect of different temperature and $\mathrm{pH}$ levels on the mecelial growth of Fusarium oxysporum f. sp. capsici was studied in vitro. In addition, the effect of edaphic factors viz. soil temperature and soil moisture on the development of Fusarium wilt disease of bell pepper was also investigated.

\section{Materials and Methods}

An experiment was conducted under in vitro in Completely Randomized Design (CRD) to evaluate the effect of temperature and $\mathrm{pH}$ on mycelial growth of $F$. oxysporum $\mathrm{f}$. sp. capsici. The 
effect of different temperature treatments i.e. 15, 20, 25, $30,35^{\circ} \mathrm{C}$ on mycelial growth of fungus was evaluated to PDA medium. Sterilized Petri plates $(90 \mathrm{~mm}$ ) containing equal amount of potato dextrose agar medium were inoculated with mycelial discs of $5 \mathrm{~mm}$ diameter taken from actively growing culture of the fungus and were incubated at different temperatures. The experiment was replicated four times.

Similarly, the effect of different $\mathrm{pH}$ treatments i.e. 4, 5, 6, $7,8,9$ on mycelial growth of $F$. oxysporum f. sp. capsici was evaluated to PDA medium in a Completely Randomized Design (CRD) with four replications. The $\mathrm{pH}$ of PDA medium was adjusted with the help of $\mathrm{N} / 10 \mathrm{HCl}$ or $\mathrm{N} / 10 \mathrm{NaOH}$. The $\mathrm{pH}$ of the medium was checked after autoclaving and adjusted, if required. Inoculated Petri plates were incubated at $25 \pm 2{ }^{\circ} \mathrm{C}$. Observations on the diametric growth of the colonies were taken at $24 \mathrm{~h}$ interval up to five days and the growth rate ( $\mathrm{rg}$ ) $\mathrm{mm}$ day $^{-1}$ at each temperature and $\mathrm{pH}$ level were calculated as: Growth rate=mycelia growth/number of days

Further, effect of soil temperature and moisture on development of Fusarium wilt of bell pepper was studied in pots under polyhouse conditions. Mass culture of $F$. oxysporum f. sp. capsici was prepared on corn:sand meal medium (Dohroo, 1988) and sick pots, at inoculum dose of $10 \mathrm{~g} \mathrm{pot}^{-1}$, were used to conduct this experiment. Four seedlings (40 days old) of bell pepper cv. 'Solan Bharpur' were transplanted and sick pots were maintained at different temperature viz. $20,25,30,35,40{ }^{\circ} \mathrm{C}$ and soil moisture viz. $20,30,40,50,60$ and $70 \%$. The experiment was conducted in Completely Randomized Design (CRD) and each treatment was replicated four times. The numbers of wilted plants at each treatment were recorded after 10 days and per cent disease incidence was calculated.

\section{Results and Discussion}

Temperature had significant effect on the growth of Fusarium spp. In the present study, the most favourable temperature for growth of $F$. oxysporum f. sp. capsici was $25^{\circ} \mathrm{C}(10.65 \mathrm{~mm}$ day $^{-1}$ ) followed by $30{ }^{\circ} \mathrm{C}\left(9.65 \mathrm{~mm} \mathrm{day}^{-1}\right)$ and $20^{\circ} \mathrm{C}(5.5 \mathrm{~mm}$ day $^{-1}$ ) (Table 1). However, diameter of colony was statistically at par at $15{ }^{\circ} \mathrm{C}$ and $35^{\circ} \mathrm{C}$. Growth rate of fungus started to decline above $30^{\circ} \mathrm{C}$. Differences in the growth of fungus

\begin{tabular}{|c|c|c|}
\hline Temperature $\left({ }^{\circ} \mathrm{C}\right)$ & $\begin{array}{l}\text { Colony diameter } \\
(\mathrm{mm})\end{array}$ & $\begin{array}{l}\text { Mycelial growth } \\
\text { rate }\left(\mathrm{mm} \mathrm{day}^{-1}\right)\end{array}$ \\
\hline 15 & $17.75^{d}$ & 3.55 \\
\hline 20 & $27.50^{c}$ & 5.50 \\
\hline 25 & $53.25^{\mathrm{a}}$ & 10.65 \\
\hline 30 & $48.25^{b}$ & 9.65 \\
\hline 35 & $21.5^{d}$ & 4.30 \\
\hline $\operatorname{CD}(p=0.05)$ & 4.94 & \\
\hline
\end{tabular}

at different temperature levels were recorded (Figure 1). Highest growth of fungus was recorded at $25{ }^{\circ} \mathrm{C}$ however, below $15^{\circ} \mathrm{C}$ and above $35^{\circ} \mathrm{C}$ growth was reduced drastically. Results of our studies are in conformity with the findings of Sharma et al. (2011) who also reported maximum growth of F. oxysporum f. sp. lycopersici at $25^{\circ} \mathrm{C}$ followed by $30^{\circ} \mathrm{C}$ while minimum average radial growth of fungus was recorded at 15 and $35^{\circ} \mathrm{C}$. Similar observations were also recorded by other workers (Gangadhara et al., 2004, Kimberly et al., 2015). They concluded that the growth of $F$. oxysporum was maximum at $25^{\circ} \mathrm{C}$ after seven days of inoculation, which reduced drastically below $15^{\circ} \mathrm{C}$ and showed zero growth at $40^{\circ} \mathrm{C}$.

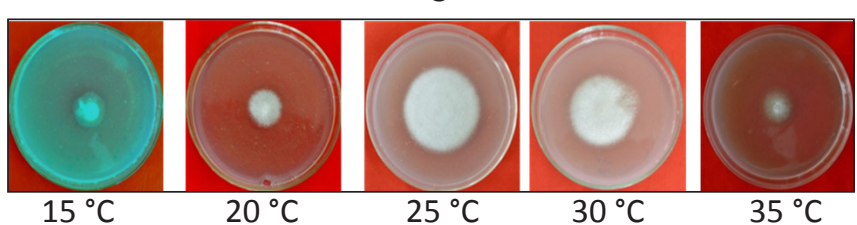

Figure 1: Effect of different temperature levels on growth of F. oxysporum f.sp. capsici

Behaviour of $F$. oxysporum f. sp. capsici at six $\mathrm{pH}$ ranging from 4 to 9 was studied with respect to their radial growth. Maximum radial growth rate of fungus was recorded at $\mathrm{pH}$ 7.0 (12.75 mm day ${ }^{-1}$ ) followed by $\mathrm{pH} 6.0$ (10.70 $\mathrm{mm} \mathrm{day}^{-1}$ ) (Table 2). Data also revealed that growth rate was increasing in ascending order $\left(6.90,8.75,10.70,12.75 \mathrm{~mm}\right.$ day $\left.^{-1}\right)$ from $\mathrm{pH}$ 4.0 to 7.0 and started to decline above $\mathrm{pH}$ level of 7.0 (Figure 2). Optimum $\mathrm{pH}$ for growth of fungus was recorded at $\mathrm{pH}$ 7.0. The studies conducted on F. oxysporum f. sp. capsici during present investigation indicated that, as the $\mathrm{pH}$ decreases or increases from the optimum, the rate of growth gradually decreased. Gangadhara et al. (2004), Kishore et al. (2009), Gupta et al. (2010) and Jaruhar and Prasad (2011) reported

Table 2: Effect of different $\mathrm{pH}$ levels on mycelial growth of F. oxysporum f. sp. capsici

\begin{tabular}{lcc}
\hline Temperature $\left({ }^{\circ} \mathrm{C}\right)$ & $\begin{array}{c}\text { Colony diameter } \\
(\mathrm{mm})\end{array}$ & $\begin{array}{c}\text { Mycelial growth } \\
\text { rate }\left(\mathrm{mm} \mathrm{day}^{-1}\right)\end{array}$ \\
\hline 4 & $34.50^{\mathrm{d}}$ & 6.90 \\
5 & $43.70^{\mathrm{c}}$ & 8.75 \\
6 & $53.50^{\mathrm{b}}$ & 10.70 \\
7 & $63.75^{\mathrm{a}}$ & 12.75 \\
8 & $49.50^{\mathrm{b}}$ & 9.90 \\
9 & $43.00^{\mathrm{c}}$ & 8.60 \\
$\mathrm{CD}(p=0.05)$ & 4.53 & \\
\hline
\end{tabular}

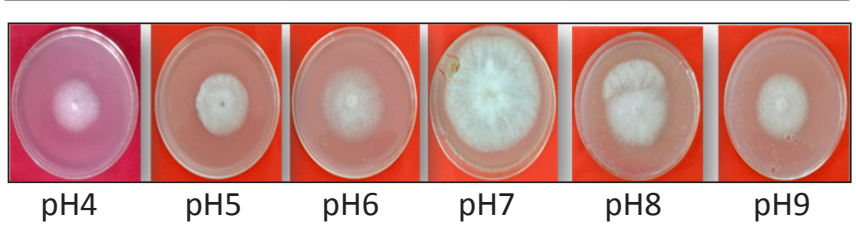

Figure 2: Effect of different $\mathrm{pH}$ levels on growth of $F$. oxysporum f.sp. capsici 
optimum $\mathrm{pH}$ range for growth and sporulation of Fusarium were in between 5.0-7.0. Present findings of $\mathrm{pH}$ are also in consonance with the findings of Kumar et al. (2012). The results of studies conducted by Hossain et al. (2015) also revealed that mycelial growth of $F$. moniliforme was maximum at $\mathrm{pH}$ range of 6.0-7.0. These reports are in agreement with present findings on F. oxysporum f. sp. capsici, those highly acidic and alkaline mediums are not suitable for growth and sporulation of the fungus.

Incidence of Fusarium wilt of bell pepper was studied on different soil temperature levels ranging between $15-40{ }^{\circ} \mathrm{C}$ (Table 3). The effect of soil temperature was found maximum at temperature level of $25^{\circ} \mathrm{C}$ with maximum incidence of disease. However, it was found that temperature range from $20-30{ }^{\circ} \mathrm{C}$ was suitable for development of disease. The disease incidence was minimum at $35^{\circ} \mathrm{C}$ whereas no disease development was occurred at 15 and $40{ }^{\circ} \mathrm{C}$ (Figure 3). This

Table 3: Effect of different temperature regimes on Fusarium wilt disease development of bell pepper

\begin{tabular}{lc}
\hline Temperature $\left({ }^{\circ} \mathrm{C}\right)$ & Disease incidence $(\%)$ \\
\hline 15 & $0.00(0.00)^{\mathrm{e}}$ \\
20 & $37.50(37.48)^{\mathrm{c}}$ \\
25 & $100.00(90.00)^{\mathrm{a}}$ \\
30 & $75.00(63.73)^{\mathrm{b}}$ \\
35 & $12.50(14.99)^{\mathrm{d}}$ \\
40 & $0.00(0.00)^{\mathrm{e}}$ \\
$\mathrm{CD}(p=0.05)$ & $(16.53)$ \\
\hline
\end{tabular}

Figures in the parenthesis are arc sine transformed value

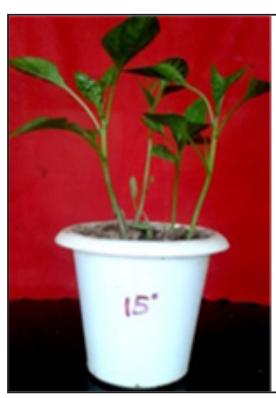

$15^{\circ} \mathrm{C}$

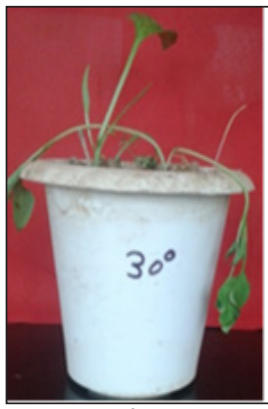

$30^{\circ} \mathrm{C}$

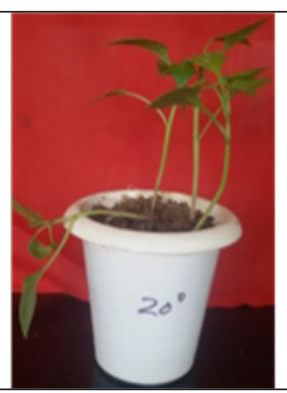
$20^{\circ} \mathrm{C}$

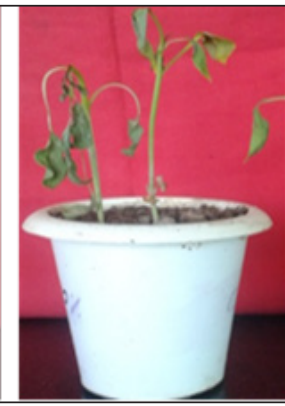

$35^{\circ} \mathrm{C}$

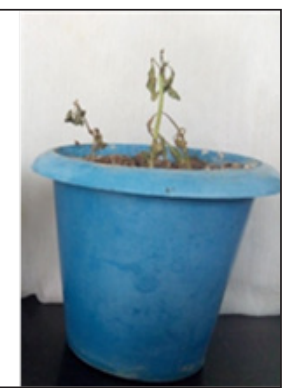

$25^{\circ} \mathrm{C}$

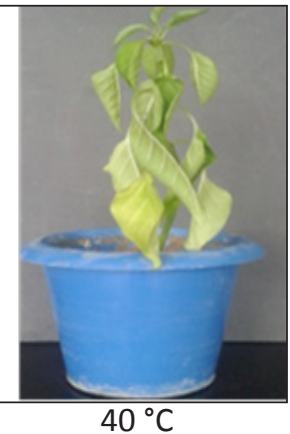

$40^{\circ} \mathrm{C}$
Figure 3: Effect of different temperature regimes on diseases development explanation is in general agreement with those obtained for disease incidence in wilt of pea caused by $F$. oxysporum f. sp. pisi (Tu, 1994), who observed that disease incidence were maximum at $25-30{ }^{\circ} \mathrm{C}$. Similar results were also obtained by Peng et al. (1999), Landa et al. (2001) and Sekhon and Singh (2007) who reported that range of soil temperature for Fusarium wilt disease development in different crops was $23-27^{\circ} \mathrm{C}$ with optimum at $25^{\circ} \mathrm{C}$. Soil temperature range of $25-30{ }^{\circ} \mathrm{C}$ was recorded best for multiplication of Fusarium udum which favours wilt disease development (Prasad and Saifulla, 2012). Results obtained from present studies indicated that optimum soil temperature for Fusarium wilt development in bell pepper was $25-30^{\circ} \mathrm{C}$. This shows that extremely low and high soil temperatures are not favourable for disease development. However, information on this aspect in bell pepper is lacking and hence cannot be compared with.

Fusarium wilt of bell pepper was affected markedly by soil moisture. It had significant influence on the disease incidence when seedlings transplanted in sick soil exposed to various moisture regimes. Data (Table 4) revealed that disease incidence varied according to different moisture regimes and maximum disease incidence of $66.66 \%$ was recorded at $40 \%$ soil moisture level followed by $50 \%(58.33 \%)$ and $60 \%$

Table 4: Effect of different soil moisture regimes on Fusarium wilt disease development of bell pepper

\begin{tabular}{lc}
\hline Moisture Level (\%) & Disease incidence (\%) \\
\hline 20 & $0.00(0.00) \mathrm{d}$ \\
30 & $25.00(29.98) \mathrm{c}$ \\
40 & $66.66(54.97) \mathrm{a}$ \\
50 & $58.33(49.98) \mathrm{a}$ \\
60 & $50.00(44.98) \mathrm{b}$ \\
70 & $16.66(19.99) \mathrm{c}$ \\
$\mathrm{CD}(p=0.05)$ & $(15.571)$ \\
\hline
\end{tabular}

Figures in the parenthesis are arc sine transformed value

(50.00\%) soil moisture level (Figure 4). The disease incidence at 40 and $50 \%$ soil moisture level were statistically at par with each other and there was no significant difference. The results of present studies clearly indicated that beyond $60 \%$ of soil moisture level, disease incidence started to decline whereas disease incidence was very low (25\%) at $30 \%$ soil moisture level and no disease incidence was recorded at $20 \%$ soil moisture level. Results of present investigations are in conformity with Fahmy and Tewfik (1928) and Fikry (1932), who observed that relatively high percentages of soil moisture were correlated with increased disease incidence. Incidence and disease severity of wilt disease of cotton (F. oxysporum) was favoured by wet soil conditions. Very low soil moisture and very high soil moisture were not favourable for Fusarium wilt development. 


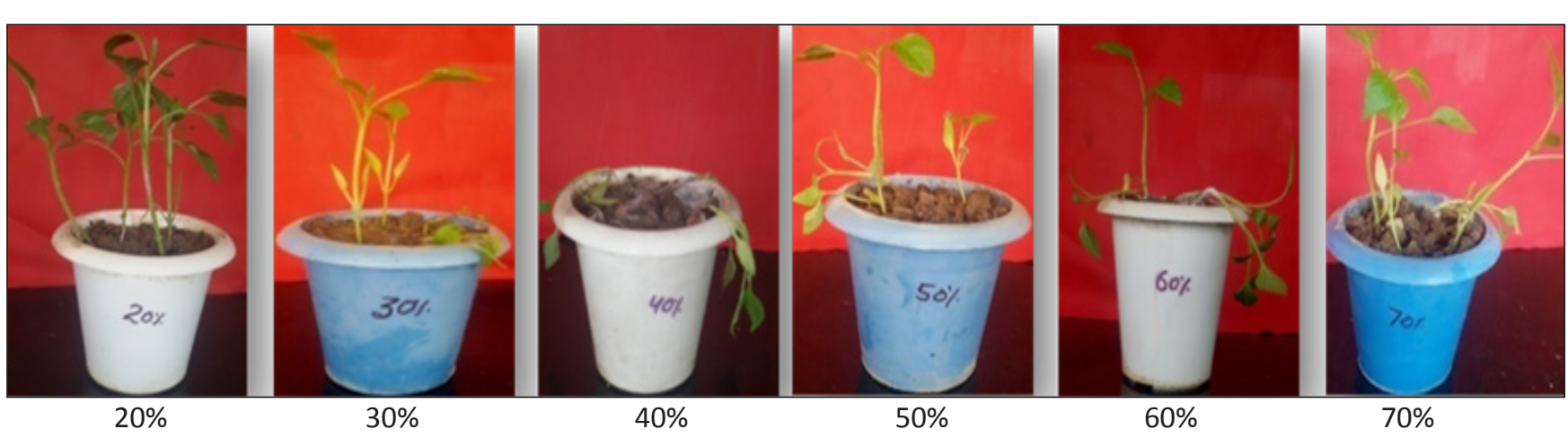

Figure 4: Effect of different soil moisture levels on diseases development

\section{Conclusion}

In order to study the thermal, moisture and $\mathrm{pH}$ requirement of Fusarium oxysporum f. sp. capsici, studies were conducted under in vitro and in vivo conditions. Optimum temperature for mycelial growth was at $25{ }^{\circ} \mathrm{C}$. Optimum $\mathrm{pH}$ level for growth of fungus was 7.0 under in vitro. Environmental conditions play a vital role in development of diseases on a particular host with pathogen. The present study revealed that maximum incidence of Fusarium wilt of bell pepper was at soil temperature of $25{ }^{\circ} \mathrm{C}$ and soil moisture of $40 \%$ in pot conditions.

\section{References}

Anonymous, 2005. Annual Report. Network project on wilt of crops, Indian Council of Agricultural Research, New Delhi $7 p$.

Black, L.L., Rivelli, V., 1990. Fusarium wilt of pepper in Louisiana. In: Proceeding $10^{\text {th }}$ National Pepper Conference, 25-27 June. Wilmington, (Delaware, E., Kee, Johnson, S.A. (Eds.), University of Delaware, Wilmington, 44.

Chen, L.H., Huang, X.Q., Yang, X.M., Shen, Q.R., 2013. Modeling the effects of environmental factors on the population of Fusarium oxysporum in cucumber continuously cropped soil. Communications in Soil Science and Plant Analysis 44(15), 2219-2232.

Dohroo, N.P., 1988. Germplasm reaction of cauliflower to stalk rot (Sclerotinia sclerotiorum). Indian Journal of Plant Pathology 6, 144.

Fahmy and Tewfik, 1928. The Fusarium disease of cotton (wilt) and its control. Egyptian Min Agricultural Technical and Sei. Service Bulletin 74, 106.

Fikry, A., 1932. Investigations on the wilt disease of Egyptian cotton caused by various species of Fusarium. Annalas of Botany 46, 29-70.

Gangadhara, N.B., Nagaraja, R., Basavaraja, M.K., Krishna, N.R., 2004. Variability studies of Fusarium oxysporum f. sp. vanillae isolates. International Journal of Science and Nature 1(1), 12-16.

Gupta, S.K., Thind, T.S., 2006. Disease problems in vegetable production. Scientific Publishers (India) Ltd., Jodhpur, India, 335-380.
Gupta, V.K., Misra, A.K., Gaur, R.K., 2010. Growth characteristics of Fusarium spp. causing wilt disease in Psidium guajava in India. Journal of Plant Protection Research 50(4), 452-462.

Hossain, M.S., Ali, M.A., Moni. Z.R., Islam, M.S., Islam, M.R., 2015. Effect of temperature and $\mathrm{pH}$ on the growth and sporulation of Fusarium moniliforme: Causing bakanae disease of rice. Scientia Agriculturae 11(3), 151-154.

Jaruhar, H.B., Prasad, A., 2011. Effect of different pH levels on the growth and sporulation of Fusarium oxysporum Schlecht. f. sp. lentis the causal organism of wilt disease of lentil. The Bioscan 6(1), 289-291.

Kimberly, M.W., Brenner, T., Jacobsen, B.J., 2015. Temperature effects on the interactions of sugar beet with Fusarium yellows caused by Fusarium oxysporum f. sp. betae. Canadian Journal of Plant Pathology 37( 3), 353-362

Kishore, R., Pandey, M., Dubey, K., Kumar, Y., 2009. Effect of temperature and $\mathrm{pH}$ on growth and sporulation of Fusarium moniliforme v. subglutinans Wr. and Rg., The causal organism of wilt of maize. Bioscience Journal 4, 75-78.

Kumar, S., Singh, J., Biswas, S.K., Prem, N.P., Dabas, M.R., 2012. Effect of culture media, temperature, $\mathrm{pH}$ and host range on the growth of Fusarium oxysporum f. sp. pisi. Journal of Mycopathological Research 50(1), 73-76.

Landa, B.B., Navas-Cort, J.A., Herv, A., Jim enez-Diaz, R.M., 2001. Influence of temperature and inoculum density of Fusarium oxysporum f. sp. ciceris on suppression of Fusarium wilt of chickpea by rhizosphere bacteria. Phytopathology 91, 807-816.

Leonian, L.H., 1919. Fusarium wilt of chile pepper. New Mexico Agricultural Experimental Station Technical Bulletin, 121.

Madhukar, H.M., Naik, M.K., 2004. Evaluation of bioagents against Fusarium wilt of chilli (Capsicum annuum var. annuum). In: Proceeding $15^{\text {th }}$ international plant protection towards $21^{\text {st }}$ century held in Beijing, China. 540.

Mina, U., Dubey, S.C., 2010. Effect of environmental variables on development of Fusarium wilt in chickpea (Cicer arietinum) cultivars. Indian Journal of Agricultural Sciences 80(3), 231.

Peng, H.X., Sivasithamparam, K., Turner, D.W., 1999. 
Chlamydospore germination and Fusarium wilt of banana plantlets in suppressive and conducive soils affected by physical and chemical factors. Soil Biology and Biochemistry 31, 1363-1374.

Prasad, P.S., Saifulla, M., 2012. Effect of soil moisture and temperature on population dynamics of Fusarium udum causing pigeonpea wilt. Trends in Biosciences 5(4), 303-305.

Sharma, B.K., Singh, R.P., Saha, S., Kumar, A., Rai, A.B., 2011. Effect of temperature, $\mathrm{pH}$ and media on the growth and sporulation of Fusarium oxysporum f. sp. Iycopersici causing wilt of tomato. Progressive Horticulture 43(2), 186-192.
Singh, A., Singh, A.K., Singh, A., 1998. Screening of chilli germplasm against Fusarium wilt. Crop Research 15, 132-133.

Smith, I.M., Dunez, J., Phillips, D.H., Lelliott, R.A., Archer, S.A., 1988. European Handbook of Plant Diseases. Blackwell Scientific Publications: Oxford 583.

Tu, J.C., 1994. Effects of soil compaction, temperature, and moisture on the development of the Fusarium root rot complex of pea in south western Ontario. Phytoprotection 75(3), 125-131. 